\title{
Aplikasi EFA (Excel For Accounting) untuk Laporan Keuangan Pesantren
}

\author{
Nurmala Ahmar \\ Sekolah Pascasarjana Universitas Pancasila, Jakarta, Indonesia \\ *E-mail: nurmala.ahmar@univpancasila.ac.id
}

\begin{abstract}
Abstrak
Pedoman Akuntansi Pesantren diterbitkan oleh Ikatan Akuntan Indonesia pada Mei 2018. Berdasarkan data Kementerian Keagamaan Republik Indonesia (Kemenag RI) terdapat total sebanyak belasan juta santri dan mendekati angka tiga puluh ribu pondok pesantren di berbagai wilayah se-Indonesia. Salah satu program untuk mendorong adalah peningkatan tata kelola yang baik di lingkungan pesantren melalui tersedianya laporan keuangan yang memenuhi standar akuntansi yang diterima secara luas dan diterima berbagai pihak. Artikel ini menyumbangkan karya pengabdian dalam bentuk pelatihan akuntansi pesantren dengan aplikasi EFA untuk memidakan penyusunan laporan keuangan pesantren.
\end{abstract}

Kata Kunci: aplikasi program, excel for accounting, akuntansi pesantren, laporan aktivitas.

\begin{abstract}
Pedoman Akuntansi Pesantren Published by the Ikatan Akuntan Indonesia in May 2018. Based on data from kementerian Agama republik Indonesia, there are a total of tens of millions of students and a count of thirty thousand Islamic boarding schools in various regions throughout Indonesia. One of the programs to encourage is the improvement of good governance in the pesantren environment through financial reportsthat meet accounting standards that are widely accepted and accepted by various parties. This article contributed dedication work in the form of Islamic boarding school accounting training with the EFA application for preparing Islamic boarding school financial reports.
\end{abstract}

Keywords: software, excel for accounting, pesantren, activity report accounting.

\section{PENDAHULUAN}

Menteri Agama Fachrul Razi memberikan informasi bahwa jumlah pesantren hingga tahun 2020 ini tercatat sebanyak 26.974 pesantren dengan lebih dari 5 juta santri mukim yang tersebar di 34 provinsi sebagai berikut: 
Tabel 1 Sebaran jumlah pesantren pada 34 provinsi di Indonesia

\begin{tabular}{|l|l|l|l|l|l|}
\hline No & Provinsi & Jumlah & No & Provinsi & Jumlah \\
\hline 1 & Aceh & 1177 & 18 & Nusa Tenggara Barat & 684 \\
\hline 2 & Sumatera Utara & 183 & 19 & Nusa Tenggara Timur & 27 \\
\hline 3 & Sumatera Barat & 211 & 20 & Kalimantan Barat & 245 \\
\hline 4 & Riau & 233 & 21 & Kalimantan Tengah & 76 \\
\hline 5 & Jambi & 229 & 22 & Kalimantan Selatan & 214 \\
\hline 6 & Sumatera Selatan & 317 & 23 & Kalimantan Timur & 163 \\
\hline 7 & Bengkulu & 52 & 24 & Kalimantan Utara & 21 \\
\hline 8 & Lampung & 676 & 25 & Sulawesi Utara & 22 \\
\hline 9 & Bangka Belitung & 53 & 26 & Sulawesi Tengah & 88 \\
\hline 10 & Kepulauan Riau & 63 & 27 & Sulawesi Selatan & 289 \\
\hline 11 & DKI Jakarta & 102 & 28 & Sulawesi Tenggara & 86 \\
\hline 12 & Jawa Barat & 8343 & 29 & Gorontalo & 28 \\
\hline 13 & Jawa Tengah & 3787 & 30 & Sulawesi Barat & 74 \\
\hline 14 & DI Yogyakarta & 319 & 31 & Maluku & 16 \\
\hline 15 & Jawa Timur & 4452 & 32 & Maluku Utara & 20 \\
\hline 16 & Banten & 4579 & 33 & Papua & 37 \\
\hline 17 & Bali & 90 & 34 & Papua Barat & 18 \\
\hline Sa & & &
\end{tabular}

Sumber: https://ditpdpontren.kemenag.go.id/pdpp/statistik

Pengembangan pesantren secara khusus telah pula menjadi salah satu target pengembangan ekonomi syariah mengingat perannya yang juga cukup strategis. Dalam implementasinya, Bank Indonesia bekerjasama dengan Kementerian Agama telah sepakat untuk menyatukan langkah dalam berbagai program pengembangan pesantren, termasuk didalamnya program peningkatan kemandirian ekonomi pesantren yang pada akhirnya akan memberikan kemampuan bukan hanya dalam aspek ekonomi akan tetapi juga dalam hal penciptaan insan-insan yang memiliki akhlak yang baik dan juga andal dalam aspek ekonomi (BI dan IAI, 2018). Afkarina (2019) mengusulkan suatu rekonstruksi akuntansi pesantren. Hal ini menjukkan bahwa akuntansi pesantren membutuhkan sebuah pedoman yang jelas agar mudah diimplementasikan.

Ikatan Akuntan Indonesia (IAI) bekerja sama dengan Bank Indonesia (BI) telah menerbitkan Pedoman Akuntansi Pesantren. Pedoman ini dibuat sebagai bentuk keberpihakan IAI dan BI akan pemberdayaan ekonomi Pondok Pesantren agar mampu menyusun laporan keuangan sesuai dengan standar akuntansi keuangan yang berlaku umum di Indonesia.

Penerapan akuntansi pesantren merupakan tantangan bagi regulator dan akademisi (Romli, 2018; Tania, 2021). Kurnia dan Kurnia (2021) melakukan observasi pada salah satu pondok pesantren di kota Ambon dan hasil observasi menemukan adanya kesultan pemaham bagi pengelola pondok pesantren dalam menerapkan akuntansi pesantren, sehingga mereka belum menerapkan. Hal yang sama ditemukan oleh Rozaidin dan Adinugraha (2020), 
Sulistiani (2020). Pada Pondok pesantren yang diamati, pengelola telah mengenal akuntansi pesantren dan masih berupaya menerapkan. Salah satu aspek penting yang menjadi kendala penerapan adalah teknik pengakuan dan pengukuran (Yohani, 2019).

Aplikasi EFA pertama kali dibuat untuk modul perkuliahan laboratorium akuntansi, sebagai bentuk praktik pemanfaatan perangkat lunak Excel untuk menyusun laporan keuangan dengan mengoptimumkan fungsi-fungsi yang ada pada software tersebut. EFA berbasis laboratorium ini digunakan untuk mngolah data transaksi untuk usaha jasa, perdagangan dan manufaktur (proses produksi). Sukses dalam memberikan keterampilan menyusun laporan keuangan ke mahasiswa, aplkasi diterapkan untuk beberapa usaha kecil. Mengacu pada pedoman akuntansi pesantren aplikasi EFA sangat cocok bila digunakan untuk menyusun laporan keuangan pesantren. Aplikasi sejenis dengan Sango Profesional pernah disosialisaikan oleh Handayati dan Muqirobin (2020). Aplikasi SANGO sendiri dikembangkan oleh Greasoft Computindo, perusahaan pengembang karya anak bangsa yang merupakan gabungan dari para ahli di bidang masing-masing. Software ini merupakan pengembangan dari PLAKON (Piranti Lunak Akuntansi dan Keuangan Organisasi Nirlaba).

\section{PEDOMAN AKUNTANSI PESANTREN}

SAK yang digunakan sebagai acuan dalam penyusunan Pedoman Akuntansi Pesantren adalah Standar Akuntansi Keuangan Entitas Tanpa Akuntabilitas Publik (SAK ETAP). Pertimbangan dalam memilih acuan kepada SAK ETAP dilandasi bahwa aset yang dikelola Pondok Pesantren relatif besar nilainya. Dimana sebagian besar aset Pondok Pesantren adalah Waqaf permanen berupa tanah (IAI, 2018).

Format Penyajian atas laporan keuangan Pondok pesantren yang diatur dalam Pedoman Akuntansi Pondok Pesantren mengaju pada PSAK 45: Pelaporan Keuangan Entitas Nirlaba. Pedoman Akuntansi Pesantren mengatur bahwa laporan keuangan lengkap yang harus disusun oleh Pondok Pesantren adalah:

1. Laporan posisi keuangan;

2. Laporan aktivitas;

3. Laporan arus kas; dan

4. Catatan atas laporan keuangan

Pedoman akuntansi pesantren ini diterapkan hanya untuk pondok pesantren yang telah berbadan hukum yayasan, dimana telah terdapat pemisahan kekayaan antara pondok pesantren dengan Pemilik Yayasan. Pedoman akuntansi pesantren tidak diterapkan pada badan usaha yang berbadan hukum yang dimiliki oleh Pondok Pesantren seperti Perseroan terbatas.

Rachmani (2020) menemukan bahwa pengetahuan akuntansi pesantren berpengaruh terhadap penyajia laporan keuanga pesantren. Kegiatan sosialisasi dan pelatihan akuntansi pesantren pernah dilakukan dan dipublikasikan oleh Niati, dkk (2019), Sherly, dkk (2019), Yuliansyah, dkk (2020). Mungaran dan Hastuti (2020) memberikan rekomendasi rekomendasi sistem akuntansi pokok yang terdiri dari format, jurnal, buku besar, hingga akhirnya menghasilkan sebuah laporan keuangan. Penyusunan sistem akuntansi pokok ini diharapkan dapat menjadi referensi dan meningkatkan akuntabilitas dan kinerja pondok pesantren. 


\section{APLIKASI EFA (EXCEL FOR ACCOUNTING) PESANTREN}

Aplikasi Excel for Accointing ini dinamakan EFA-Pesantren. EFA-Pesantren didesain terdiri dari 7 sheet kertas kerja yang terdiri dari:

1. Petunjuk Operasi Manual

2. Buku Besar/Ledger

3. Saldo awal

4. Jurnal

5. Laporan Aktivitas

6. Laporan Arus Kas

7. Laporan Posisi Keuangan

8. Laporan Unit

Masing-masing kertas kerja memiliki fungsi sebagai berikut:

1. Buku besar/ledger digunakan untuk mendesain daftar rekening buku besar dan pembantu yang dibutuhkan untuk menyusun laporan keuangan.

2. Saldo awal digunakan sebagai kertas kerja menginput data saldo awal untuk akunakun posisi keuangan (aset, liabilitas dan aset neto)

3. Jurnal digunakan untuk menginput transaksi

4. Laporan aktivitas didesain dapat secara otomatis membaca tarnsaksi pada kertas kerja jurnal untuk mencakup perubahan aset neto tidak terikat, perubahan aset neto temporer, perubahan aset neto tidak permanen, untuk mendapatkan informasi aset neto akhir tahun.

5. Laporan arus kas didesain dapat secara otomatis membaca tarnsaksi pada kertas kerja jurnal yang terkait kas masuk dan keluar dan dikelompokkan berdasarkan kelompok arus kas operasi, investasi dan pendanaan

6. Laporan posisi keuangan dapat secara otomatis dengan fungsi yang didesain dapat menyimpan secara akumulatif komponen laporan posisi keuangan yang terdiri dari aset, liabilitas dan aset neto serta saldo awal pada tahun pertama pelaporan. Pada tahu selanjutnya, aplikasi secara mengakumulasi jumlah komponen tersebut. Informasi didesain dan tersimpan secara akumulatif dan dapat ditampilkan per bulan

7. Laporan Unit, laporan ini merupakan laporan tambahan bilamana pesantren memiliki beberapa unit kegiatan yang memerukan laporan keuangan terpisah. Aplikasi disdesain dengan mempertimbangakan kode-kode unit, bilama pesantren berkembang dan membutuhkan berbagai laporan dan konsolidasi dari berbagai laporan unit-unit.

Aplikasi EFA Pesantren dilengkapi dengan Petunjuk Operasi Manual agar memudahkan pengguna dalam menggunakan aplikasi tersebut. Berikut tampilan halaman muka Petunjuk Operasi Manual. 


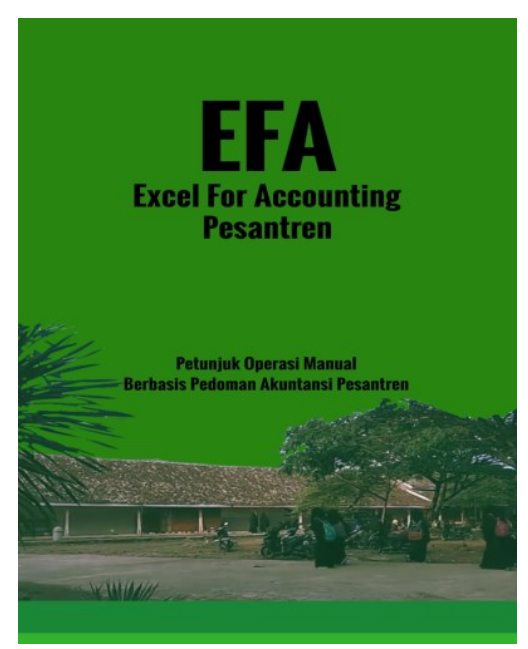

Gambar 1: Petunjuk Operasi Manual EFA Pesantren

\section{SIMPULAN}

Jumlah pesantren yang cukup banyak di Indonesia merupakan potensi yang besar dalam mengembangkan ekonomi syariah di Indonesia. Kemampuan menyusun laporan keuangan pesantren membutuhkan aktivitas pemberdayaan dari akademik. IAI dan BI telah menerbitkan Pedoman Akunansi Pesantren. Sosialisasi dan implementasi pedoman dalam bentuk pelatihan dan ide-ide pengabdian masyarakat sangat diperlukan.

EFA (Excel fir Accounting) merupakan salah satu kepedulian akademisi dalam pemberdayaan untuk meningkatkan kompetensi sumberdaya pesantren dalam menyusun laporan keuangan.Aplikasi disusun dengan software Microsoft Excel yang sudah banyak dikenal oleh masyarakat. Aplikasi disusun dengan mudah dan petunjuk operasional yang jelas agar mudah dioperasionalkan. Luaran aplikasi berupa Laporan Aktivitas, Laporan Posisi Keuangan, Laporan Arus Kas dan Laporan Unit Untuk menyebarluaskan aplikasi ini perlu kegiatan pengabdian kepada masyarakat secara berseri dari pesantren ke pesantren agar kompetensi sumberdaya manusia di pesantren meningkat khususnya dalam menyusun laporan keuangan pesantren.

\section{REFERENSI}

Afkarina, I. A. (2019). Rekonstruksi Penyusunan Laporan Keuangan di Pondok Pesantren Al-Anwari Banyuwangi (Dalam Perspektif Pedoman Akuntansi Pesantren).

Handayati, P., \& Muqorobin, M. M. (2020). Aplikasi Akuntansi Pesantren Dalam Penyusunan Laporan Keungan Digital Dengan Software SANGO Profesional.

Ikatan Akuntan Indonesia, Bank Indonesia, (2018) Pedoman Akuntansi Pesantren.Diterbitkan Bank Indonesia.

Kurnia, R., \& Kurnia, W. I. (2021). Evaluasi penerapan pedoman akuntansi pesantren (pap) pada yayasan pondok pesantren al-anshor kota Ambon. Amal: Jurnal Ekonomi Syariah, 2(2). 
Munggaran, S. M., \& Hastuti, H. (2020, September). Penyusunan Sistem Akuntansi Pokok Pondok Pesantren Daarul Haliim Berdasarkan Pedoman Akuntansi Pesantren. In Prosiding Industrial Research Workshop and National Seminar (Vol. 11, No. 1, pp. 1268-1274).

Niati, A., Suhardjo, Y., Wijayanti, R., \& Hanifah, R. U. (2019). Pelatihan Pengelolaan Manajemen Keuangan dan Pelaporan Keuangan Akuntansi Pesantren bagi Pengelola Yayasan Pondok Pesantren X di Kota Semarang. Jurnal Surya Masyarakat, 2(1), 7679.

Rachmani, F. A. (2020). Pengaruh pengetahuan tentang pedoman akuntansi pesantren terhadap penyajian laporan keuangan pesantren. In Proceeding of National Conference on Accounting \& Finance (Vol. 2, pp. 39-46).

Romli, M. (2018). Peluang dan tantangan penerapan sistem akuntansi pesantren Indonesia (SANTRI) di Indonesia. 35-51

Rozaidin, M., \& Adinugraha, H. H. (2020). Penerapan Akuntansi Pondok Pesantren (Studi pada Koperasi Pondok Pesantren Al Hasyimi Kabupaten Pekalongan). EKONOMIKA SYARIAH: Journal of Economic Studies, 4(2), 123-135.

Serly, V., Arza, F. I., Betavia, A. E., \& Zulvia, Y. (2019, December). Peningkatan Kualitas Laporan Keuangan Pesantren Melalui Pelatihan Akuntansi Pesantren Di Kota Padang Sumatera Barat. In Seminar Nasional Hasil Penelitian \& Pengabdian Kepada Masyarakat (SNP2M) (pp. 516-521).

Sulistiani, D. (2020). Akuntansi pesantren sesuai SAK ETAP dan PSAK 45 dalam penyusunan laporan keuangan pesantren. AKTSAR: Jurnal Akuntansi Syariah, 3(1), $31-48$.

Tania, A. L. (2021). Urgensi Pedoman Akuntansi Pesantren Dalam Pelaporan Keuangan. Adzkiya: Jurnal Hukum dan Ekonomi Syariah, 8(02), 211-232.

Yohani, Y. (2019). Implementasi Pengakuan dan Pengukuran Akuntansi Pondok Pesantren. Neraca, 15(2), 1-9.

Yuliansyah, Y., Dewi, F. G., \& Amelia, Y. (2020). Pelatihan Standar Akuntansi Pesantren dalam penyusunan laporan keuangan bagi staf keuangan pondok pesantren. Yumary: Jurnal Pengabdian Kepada Masyarakat, 1(1), 11-17. 